\title{
Pestisida Organoklorin dalam Air dari Daerah Jabodetabek: Studi Pada Daerah Padat Penduduk
}

Organochlorine Pesticides (OCPs) In Water from Jabodetabek: A Study in Highly Urbanized Area

\author{
Ahmad Shoiful $^{1)}$, Rudi Nugroho' ${ }^{1)}$, Hiroyuki Fujita ${ }^{2)}$, Katsuhisa Honda ${ }^{2)}$ \\ ${ }^{1)}$ Pusat Teknologi Lingkungan, Badan Pengkajian dan Penerapan Teknologi (BPPT), Indonesia \\ ${ }^{2)}$ Environmental Science for Industry Laboratory, Environmental Conservation Department, Faculty of \\ Agriculture, Ehime University, Japan
}

\begin{abstract}
Abstrak
Organochlorine pesticides (OCPs) dalam air yang diambil dari lima titik di area Jabodetabek telah diukur konsentrasinya menggunakan HRGC-HRMS. Dari total 21 senyawa OCPs, hanya beberapa senyawa OCPs terdeteksi dalam sampel air. Dari isomer senyawa $\mathrm{HCH}$, hanya $\mathrm{GHCH}$ dan lindane ( $\mathbb{H C H}$ ) yang terdeteksi dengan konsentrasi masing-masing pada kisaran ND-0,25 ng/L dan 0,083 - 0,82 ng/L. Hasil yang menarik didapatkan pada sampel air dari sungai Ciliwung, Pluit, Jakarta, dimana HCB terdeteksi pada konsentrasi yang relatif cukup tinggi yaitu 688,28 $\mathrm{ng} / \mathrm{L}$. Senyawa HCB tidak hanya diproduksi secara disengaja sebagai pestisida, namun juga dihasilkan dari produk samping proses industri. Oleh karena itu, kontaminasi tersebut kemungkinan berasal dari proses industri yang berada di sekitar lokasi titik sampling. Bila dibandingkan dengan kriteria mutu kualitas air sungai PP No. 82 Tahun 2001, konsentrasi pestisida organoklorin masih di bawah standar kualitas air kelas 1 .
\end{abstract}

Kata Kunci : organochlorine pesticides (OCPs), air, Indonesia, produk samping industri.

\begin{abstract}
Organochlorine pesticides (OCPS) in waters from five sampling point in Jabodetabek area have been determined using HRGC-HRMS. A total of 21 OCPs have been analyzed, however only few of OCPs were detected. Among $\mathrm{HCH}$ isomers, only $-\mathrm{HCH}$ and lindane ( $-\mathrm{HCH})$ were detected with concentration in the range of $N D-0,25 \mathrm{ng} / \mathrm{L}$ and 0,083-0,82 $\mathrm{ng} / \mathrm{L}$, respectively. Interesting result was found, where $H C B$ was detected in relatively high in water of Ciliwung river, Pluit Jakarta with concentration of 688,28 ng/L. HCB is a compound which is not only intentionally produced as pesticide, but also unintentionally produced from industrial by-product. Therefore, contamination of the river water may come from industrial processes which are located near sampling point. If compared with river water quality criteria of PP No.82 Tahun 2001, it results were below the standard of river water quality Class I.
\end{abstract}

Keywords : organochlorine pesticides (OCPs), waters, Indonesia, industrial by-products.

\section{PENDAHULUAN}

Pestisida Organoklorin (OCPs) merupakan salah satu grup bahan kimia yang termasuk dalam persistent organic pollutants (POPs) berdasarkan Konvensi Stockholm. Bahan-bahan kimia tersebut dan metabolitnya sangat berbahaya karena dapat terakumulasi, dan berpindah dalam rantai makanan dan dapat menyebabkan dampak buruk terhadap kesehatan seperti kanker dan kerusakankelenjar endocrine (UNEP, 2001). Keberadaan bahan-bahan berbahaya tersebt di alam dapat menyebabakan masalah kesehatan terhadap hewan dan manusia baik melalui udara, air, maupun makanan (Darko et al., 2008).

Senyawa-senyawa organoklorin sangat stabil di lingkungan dan dapat terakumulasi dalam tubuh makhluk hidup. Banyak studi yang telah dilakukan menunjukkan bahwa pestisida organoklorin masih terdeteksi di dalam makhluk hidup meskipun bahanbahan tersebut sudah dilarang sejak tahun 1980an di 
negara-negara maju (Fair et al, 2010; Ueno et al, 2010; Karen et al, 2010).

Indonesia merupakan salah satu negara agraris. Beberapa senyawa OCPs pernah digunakan di sektor pertanian untuk mengontrol hama. Pada tahun 1974, total impor dan produksi untuk aldrin, klordan, dan toksaphene adalah masing-masing sebesar $30.000 \mathrm{~kg}, 20.902 \mathrm{~kg}$, dan $144 \mathrm{~kg}$. Sedangkan pada tahun 1979, dieldrin dan klordan diimpor sebanyak $3.000 \mathrm{~kg}$ dan $3.720 \mathrm{~kg}$. Data penggunaan dieldrin pada tahun 1990 sebesar $3.492 \mathrm{~kg}$. Sementara penggunaan klordan meningkat dari tahun 1990 sebesar $21.072 \mathrm{~kg}$ menjadi $37.871 \mathrm{~kg}$ pada tahun 1992. DDT pernah digunakan secara luas sebagai control malaria. Penggunaan rata-rata pada tahun 1974 sebesar 2.628 ton/tahun, meningkat dari tahun 1969 sebesar 1.145 ton/tahun (Untung Kasumbogo, 1999). Tingginya penggunaan DDT pada masa tersebut, Montrose Chemical USA mendirikan pabrik DDT di Bogor, Indonesia (UNIDO, 1984).

Tabel 1 : Status penggunaan senyawa OCPs di Indonesia

\begin{tabular}{|c|c|}
\hline Senyawa & Status \\
\hline & $\mathrm{HCH}$ isomer- dilarang \\
\hline $\mathrm{HCH}$ & $\begin{array}{l}\text { Lindane - tidak pernah teregister } \\
\text { untuk digunakan }\end{array}$ \\
\hline $\mathrm{HCB}$ & Dilarang \\
\hline Aldrin & $\begin{array}{l}\text { Tidak pernah teregister untuk } \\
\text { digunakan }\end{array}$ \\
\hline Dieldrin & Dilarang sejak 1992 \\
\hline Endrin & $\begin{array}{l}\text { Tidak pernah teregister untuk } \\
\text { digunakan }\end{array}$ \\
\hline Heptachlor & $\begin{array}{l}\text { Tidak pernah teregister untuk } \\
\text { digunakan }\end{array}$ \\
\hline Chlordane & Dilarang sejak 1992 \\
\hline DDT & Dilarang sejak 1992 \\
\hline Mirex & Dilarang \\
\hline
\end{tabular}

Sumber: UNEP, 2002

Pada penelitian sebelumnya, dilaporkan bahwa OCPs terdeteksi di bahan makanan dan air susu ibu di Indonesia (A. Shoiful et al., 2013, Sudaryanto et al., 2006,). PCB dan PCDD juga terdeteksi pada air dari daerah perkotaan Jabodetabek (Shoiful et al., 2014). Sebagai kelanjutan dari studi tersebut, maka pada studi ini, akan dianalisis kandungan pestisida organoklorinnya dan hasilnya dibandingkan dengan PP No. 82 Tahun 2001 tentang pengelolaan kualitas air dan pengendalian pencemaran.

\section{METODE}

\subsection{Lokasi Studi}

Studi ini mengambil lokasi di Jabodetabek, yang merupakan daerah yang paling padat penduduknya di Indonesia. Di daerah Bogor yang merupakan daerah hulu merupakan area perkebunan, sehingga pestisida dan pupuk merupakan sumber utama pencemar. Sedangkan di area Jakarta atau area hilir merupakan daerah perkotaan dan juga industri, dimana sumber pencemaran yang utama adalah dari domestik dan juga industri.

\subsection{Pengambilan dan Penyiapan Sampel}

Sampel air diambil dari lima titik di area Jabotabek pada bulan Agustus 2010, yaitu mulai dari air sumur di kawasan Puncak, Bogor, air sungai Ciliwung di Bogor sampai Pluit, Jakarta Utara, dan air sungai di daerah budidaya perikanan bandeng Kosambi, Tangerang (lihat pada Gambar 1).

Sampel air sebanyak $500 \mathrm{~mL}$ dilewatkan pada kolom Sepabeads dan PS@Liq Autoprep, yang digunakan sebagai substrat untuk mengikat senyawa POPs. Kolom tersebut kemudian disimpan dalam kantong plastik tertutup "Zipfloc" dan suhu -20 oC untuk kemudian dianalisis. Sedangkan sampel air yang diambil dari sungai Ciliwung, karena mengandung partikel yang tinggi, langsung diambil dan disimpan dalam botol. Seluruh sampel dikirim ke Universitas Ehime, Jepang untuk dianalisis.

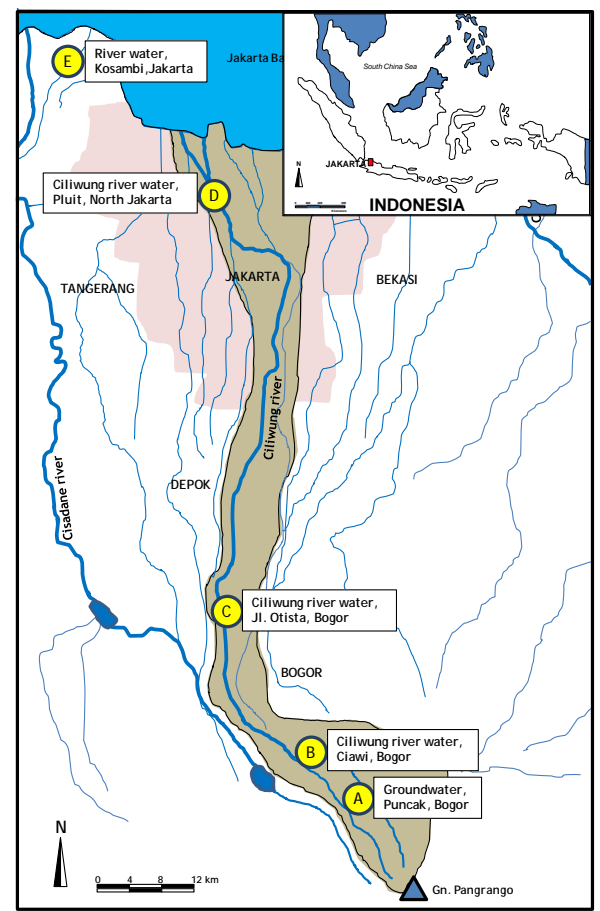

Gambar 1 : Lokasi pengambilan sampel di daerah Jabodetabek 


\subsection{Metode ekstraksi}

Kolom Sepabeads ${ }^{\circledR} /$ PS@Liq ${ }^{\circledR}$ Autoprep yang telah digunakan untuk pengambilan sampel air dilewatkan dengan aseton $20 \mathrm{~mL}$ untuk fraksi pertama, dan kemudian heksan:diklorometan (1:1) $20 \mathrm{~mL}$ untuk fraksi kedua. Aseton pada fraksi pertama diekstraksi dengan diklorometan yang hasilnya dikombinasi dengan hasil fraksi kedua. Hasil ekstraksi tersebut kemudia dipurifikasi dengan kolom $10 \%(\mathrm{w} / \mathrm{w})$ silver nitrate-silica gel $(3 \mathrm{~g})$, dan dilewatkan dengan $10 \%$ dichloromethane:hexane $160 \mathrm{~mL}$ sebelum dianalisi dengan HRGC/HRMS.

Sedangkan untuk air yang diambil dari sungai Ciliwung, Pluit, ditambahkan dengan Dioflock ${ }^{\circledR}$, reagen koagulan yang berfungsi untuk mengikat senyawa OCPs, kemudian disaring dengan kertas saring. Untuk fase cair diekstraksi dengan metode ekstraksi dengan diklorometan, sedangkan fase pada pada kertas saring diekstraksi dengan ekstraktor Soxhlet dengan toluene selama 16 jam. Hasil ekstraksi keduanya kemudian dikombinasi dan dipurifikasi dengan kolom $10 \%(\mathrm{w} / \mathrm{w})$ silver nitratesilica gel (3 g) dan dilewatkan dichloromethane : hexane $160 \mathrm{~mL}$ sebelum dianalisis dengan HRGC/HRMS.

\subsection{Analisis Organochlorine pesticides (OCPs) dengan HRGC-HRMS}

Gas chromatography (GC) resolusi tinggi (Hewlett Packard GC Agilent 6890 series) ditandem dengan Mass Spectrometer JMS-700D dan JMS 800D, JEOL Ltd, Japan) menggunakan kolom kapiler HT8PCB (ketebalan film $0.25 \mu \mathrm{m}$, panjang $60 \mathrm{~m}$, diameter $0.25 \mathrm{~mm}$, SGE) digunakan untuk menganalisis OCPs. Suhu injector inlet diatur pada $220^{\circ} \mathrm{C}$. Suhu oven GC diatur sebagai berikut; suhu awal oven $120^{\circ} \mathrm{C}$, waktu awal 1 min, meningkat menjadi $180{ }^{\circ} \mathrm{C}$ dengan laju $20{ }^{\circ} \mathrm{C}$ min $^{-1}$ dan kemudian $210{ }^{\circ} \mathrm{C}$ dengan laju $2{ }^{\circ} \mathrm{C}$ $\mathrm{min}^{-1}$ dan $310{ }^{\circ} \mathrm{C}$ dengan laju $5^{\circ} \mathrm{C} \mathrm{min}^{-1}$ dengan waktu final selama $3 \mathrm{~min}$. Gas helium ( $\mathrm{He}$ ) digunakan sebagai gas pembawa dengan laju alir $1.5 \mathrm{ml} \mathrm{min}^{-1}$. Mass Spektrometri diatur sebagai berikut; suhu interface dan suhu sumber ionisasi diatur pada suhu masing-masing $280{ }^{\circ} \mathrm{C}$. Mode ionisasi, arus, energi masing-masing diatur pada El positif, $500 \mu \mathrm{A}$, dan 10kV. Resolusi diatur lebih tinggi dari 10,000 dan diatur pada mode SIM.

Kurva standar didapatkan dari larutan standar OCPs dengan konsentrasi $0.5,2,10,50$, dan 100 $\mathrm{ng} / \mathrm{mL}$. Analisis OCPs dengan HRGC/HRMS menggunakan metode grouping berdasarkan waktu retensi dari tiap-tiap senyawa OCPs. Data akuisisi dikontrol dengan program JEOL Diok. Rata-rata dari kromatogram SIM monitor ion 1 dan 2 digunakan untuk menghitung konsentrasi OCPs.

\subsection{Quality assurance/ quality control (QA/QC)}

\subsubsection{Sampel blanko}

Prosedur pengetesan sampel blanko dilakukan untuk mengevaluasi interferensi dan kontaminasi. Hasil pengujian dengan blanko menunjukkan tidak terdapat kontaminasi selama proses analisis, termasuk pada tahap ekstraksi, clean up, dan kuantifikasi.

\subsubsection{Recoveri}

Recoveri dari OCPs berada pada kisaran yang dapat diterima, yaitu antara 50 \% sampai dengan $120 \%$.

2.5.3 Limit of Detection (LOD) dan Limit of Quantification (LOQ)

Minimum limit of detection (LOD) dan minimum limit of quantification (LOQ) dihitung dengan 3-kali and 10-kali dari standar deviasi (STDEV) dari lima kali analisis standard OCPs. LOD OCPS berada pada kisaran 0.03-0.7 $\mathrm{ng} / \mathrm{L}$.

\subsection{Hasil dan Pembahasan}

Lima sampel air yang diambil dari beberapa sumber di wilayah Jabodetabek, yaitu air tanah di Puncak-Bogor (water A), air sungai Ciliwung di Gadog-Bogor (water B), air sungai Ciliwung di Jl. Otista-Bogor (water C), air sungai Ciliwung di PluitJakarta Utara (water D), dan air sungai di KosambiTangerang (water E), telah dianalisis konsentrasi pestisida organoklorin (OCPs) menggunakan HRGCHRMS (tabel 1). Beberapa senyawa OCPs terdeteksi dengan konsentrasi yang berbeda-beda. Senyawa lindane $(\gamma-\mathrm{HCH})$ terdeteksi di semua sampel dengan konsentrasi antara 0,083-0,82 ng/L. Sedangkan $\alpha-$ $\mathrm{HCH}$ terdeteksi pada sampel water $\mathrm{B}(0,14 \mathrm{ng} / \mathrm{L})$, water $C(0,13 \mathrm{ng} / \mathrm{L})$, water $D(0,25 \mathrm{ng} / \mathrm{L})$, dan water $\mathrm{E}$ $(0,15 \mathrm{ng} / \mathrm{L})$. Hasil tersebut mengkonfirmasi pada hasil pengukuran sebelumnya pada tahun 2001, dimana pada air sungai Ciliwung di Ciawi Bogor terdeteksi $\alpha$ $\mathrm{HCH}$ dan $\gamma-\mathrm{HCH}$ dengan konsentrasi masing-masing $1,49 \mathrm{ng} / \mathrm{L}$ dan $5,43 \mathrm{ng} / \mathrm{L}$, dan pada studi yang lebih kini, pada tahun 2002-2003, $\alpha-\mathrm{HCH}$ and $\gamma-\mathrm{HCH}$ terdeteksi dengan konsentrasi masing-masing 5,80 $\mathrm{ng} / \mathrm{L}$ dan 0,12 ng/L (Ratnaningsih et al., 2002; EMC, 2003). Selain itu, $\alpha-\mathrm{HCH}$ and lindane $(\gamma-\mathrm{HCH})$ juga terdeteksi pada sediment sungai Ciliwung, Ciawi, Bogor dengan konsentrasi masing-masing 9,83 ng/L and 2,16 ng/L (EMC, 2003). Dari hasil penelitian tersebut, konsentrasi lindane $(\gamma-\mathrm{HCH})$ lebih tinggi dibandingkan dengan $\alpha-\mathrm{HCH}$, menunjukkan adanya penggunaan lindane dibandingkan dengan technical $\alpha-\mathrm{HCH}$. Meskipun di Indonesia $\mathrm{HCH}$ isomer statusnya dilarang digunakan dan lindane tidak pernah teregister untuk digunakan sebagai pestisida pertanian, namun lindane pernah digunakan sebagai obat kutu rambut. 
Table 2 : Metode grouping pada analisis senyawa organoklorin dengan HRGC/HRMS

\begin{tabular}{|c|c|c|c|c|}
\hline \multirow{2}{*}{ Group } & \multirow{2}{*}{ Senyawa OCPs } & \multirow{2}{*}{ Waktu retensi (min) } & \multicolumn{2}{|c|}{ Accurate mass $(\mathrm{m} / \mathrm{z})$} \\
\hline & & & 1 & 2 \\
\hline & Senyawa target & & & \\
\hline 1 & $\alpha-\mathrm{HCH}$ & 13.255 & 216.9145 & 218.9116 \\
\hline 1 & $\mathrm{HCB}$ & 13.592 & 246.8443 & 248.8413 \\
\hline 1 & $\gamma-\mathrm{HCH}$ (lindane) & 15.149 & 216.9145 & 218.9116 \\
\hline 1 & $\beta-\mathrm{HCH}$ & 15.426 & 216.9145 & 218.9116 \\
\hline 1 & $\delta-\mathrm{HCH}$ & 17.213 & 216.9145 & 218.9116 \\
\hline 1 & Heptachlor & 17.901 & 271.8102 & 273.8072 \\
\hline 1 & Aldrin & 20.306 & 262.8570 & 264.8540 \\
\hline 2 & Oxychlordane & 22.398 & 386.8052 & 388.8023 \\
\hline 2 & cis-Heptachlor Epoxide & 22.744 & 352.8442 & 354.8413 \\
\hline 2 & trans-Heptachlor Epoxide & 23.038 & 352.8442 & 354.8413 \\
\hline 3 & $o, p^{\prime}-D D E$ & 24.256 & 246.0003 & 247.9974 \\
\hline 3 & trans-Chlordane & 24.450 & 372.8260 & 374.8230 \\
\hline 3 & trans-Nonachlor & 24.688 & 406.7870 & 408.7840 \\
\hline 3 & cis-Chlordane & 25.027 & 372.8260 & 374.8230 \\
\hline 4 & $p, p^{\prime}-D D E$ & 26.116 & 235.0081 & 237.0052 \\
\hline 4 & Dieldrin & 26.373 & 262.8570 & 264.8540 \\
\hline 4 & o,p'-DDD & 26.845 & 235.0081 & 237.0052 \\
\hline 4 & Endrin & 27.763 & 262.8570 & 264.8540 \\
\hline 4 & o,p'-DDT & 28.250 & 235.0081 & 237.0052 \\
\hline 4 & cis-Nonachlor & 28.387 & 406.7870 & 408.7840 \\
\hline 4 & $p, p^{\prime}-D D D$ & 28.988 & 235.0081 & 237.0052 \\
\hline 4 & $p, p^{\prime}-D D T$ & 30.376 & 235.0081 & 237.0052 \\
\hline \multirow[t]{2}{*}{5} & Mirex & 33.539 & 271.8102 & 273.8072 \\
\hline & Senyawa Internal standard & & & \\
\hline 1 & ${ }^{13} \mathrm{C}-\alpha-\mathrm{HCH}$ & 13.239 & 222.9347 & 224.9317 \\
\hline 1 & ${ }^{13} \mathrm{C}-\mathrm{HCB}$ & 13.583 & 252.8644 & 254.8614 \\
\hline 1 & ${ }^{13} \mathrm{C}-\gamma-\mathrm{HCH}$ (lindane) & 15.133 & 222.9347 & 224.9317 \\
\hline 1 & ${ }^{13} \mathrm{C}-\beta-\mathrm{HCH}$ & 15.410 & 222.9347 & 224.9317 \\
\hline 1 & ${ }^{13} \mathrm{C}-2 \mathrm{CB}(\mathrm{PCB} \# 15)$ & 15.431 & 234.0406 & 236.0376 \\
\hline 1 & ${ }^{13} \mathrm{C}-\delta-\mathrm{HCH}$ & 17.196 & 222.9347 & 224.9317 \\
\hline 1 & ${ }^{13} \mathrm{C}$-Heptachlor & 17.874 & 276.8269 & 278.8240 \\
\hline 1 & ${ }^{13} \mathrm{C}$-Aldrin & 20.274 & 269.8805 & 271.8775 \\
\hline 2 & ${ }^{13} \mathrm{C}$-Oxychlordane & 22.369 & 396.8388 & 398.8358 \\
\hline 2 & ${ }^{13} \mathrm{C}$-cis-Heptachlor epoxide & 22.718 & 362.8778 & 364.8748 \\
\hline 3 & ${ }^{13} \mathrm{C}-\mathrm{o}, \mathrm{p}^{\prime}-\mathrm{DDE}$ & 24.241 & 327.9783 & 329.9753 \\
\hline 3 & ${ }^{13} \mathrm{C}$-trans-Chlordane & 24.424 & 382.8595 & 384.8566 \\
\hline 3 & ${ }^{13} \mathrm{C}$-trans-Nonachlor & 24.664 & 416.8205 & 418.8176 \\
\hline 4 & ${ }^{13} C-p, p^{\prime}-D D E$ & 26.099 & 258.0406 & 260.0376 \\
\hline 4 & ${ }^{13} \mathrm{C}$-Dieldrin & 26.345 & 267.8834 & 269.8805 \\
\hline 4 & ${ }^{13} \mathrm{C}-\mathrm{o}, \mathrm{p}^{\prime}-\mathrm{DDD}$ & 26.826 & 247.0484 & 249.0454 \\
\hline 4 & ${ }^{13} \mathrm{C}$-Endrin & 27.736 & 267.8834 & 269.8805 \\
\hline 4 & ${ }^{13} \mathrm{C}-0, p^{\prime}-\mathrm{DDT}$ & 28.234 & 247.0484 & 249.0454 \\
\hline 4 & ${ }^{13} \mathrm{C}$-cis-Nonachlor & 28.368 & 267.8834 & 269.8805 \\
\hline 4 & ${ }^{13} C-p, p^{\prime}-D D D$ & 28.970 & 247.0484 & 249.0454 \\
\hline 4 & ${ }^{13} C-p, p^{\prime}-D D T$ & 30.360 & 247.0484 & 249.0454 \\
\hline 5 & ${ }^{13} \mathrm{C}$-Mirex & 33.519 & 276.8269 & 278.8240 \\
\hline
\end{tabular}


Tabel 3 : Minimum limit of detection for sample (LOD) dan minimum limit of quantification untuk sampel (LOQ) untuk analisis OCPs dengan HRGC-HRMS (ng/l)

\begin{tabular}{lcllll}
\hline OCPs & LOD & LOQ & OCPs & LOD & LOQ \\
\hline \hline$\alpha$-HCH & 0.1 & 0.3 & cis-Chlordane & 0.06 & 0.2 \\
$\beta$-HCH & 0.1 & 0.2 & trans-Chlordane & 0.03 & 0.1 \\
$\gamma$-HCH (Lindane) & 0.05 & 0.2 & cis-Nonachlor & 0.1 & 0.2 \\
$\delta$-HCH & 0.1 & 0.2 & trans-Nonachlor & 0.03 & 0.1 \\
HCB & 0.7 & 2.4 & $o, p^{\prime}$-DDE & 0.1 & 0.2 \\
Aldrin & 0.0 & 0.1 & $p, p^{\prime}$-DDE & 0.1 & 0.2 \\
Dieldrin & 0.04 & 0.1 & $o, p^{\prime}$-DDD & 0.03 & 0.1 \\
Endrin & 0.08 & 0.3 & $p, p^{\prime}$-DDD & 0.03 & 0.1 \\
Heptachlor & 0.08 & 0.3 & $o, p^{\prime}$-DDT & 0.1 & 0.2 \\
cis-Heptachlor Epoxide & 0.03 & 0.1 & $p, p^{\prime}$-DDT & 0.1 & 0.2 \\
trans-Heptachlor Epoxide & 0.08 & 0.3 & Mirex & 0.03 & 0.1 \\
Oxychlordane & 0.04 & 0.1 & & & \\
& & & & & \\
\hline
\end{tabular}

Senyawa OCPs lainnya hanya terdeteksi pada sampel water $\mathrm{D}$ dan water $\mathrm{E}$. Pada sampel water $\mathrm{D}$ dan water $E$, dieldrin, cis-chlordane dan transchlordane telah terdeteksi. Senyawa-senyawa tersebut tersebut kemungkinan berasal dari penggunaan masa lalu, dimana dieldrin dan chlordane pernah digunakan di Indonesia pada sektor pertanian tahun 1974- 1992 (Kasumbogo, 1999). Sedangkan dari kelompok DDT, hanya p,pDDE yang terdeteksi pada sampel water E dengan konsentrasi $0,21 \mathrm{ng} / \mathrm{L}$. Hal tersebut menunjukkan bahwa $p, p^{\prime}-D D E$ tersebut berasal dari penggunaan DDT pada masa lalu dan tidak ada penggunaan baru.

Hal yang sangat menarik dari penelitian ini adalah terdeteksinya HCB pada sampel water D dengan konsentrasi yang cukup yaitu sebesar 688,28 ng/L. Tingginya konsentrasi tersebut kemungkinan berasal dari kontaminasi dari proses industry. HCB diproduksi secara disengaja sebagai pestisida dan juga tidak disengaja diproduksi dari proses industry, seperti dari industry pestisida, kimia dan juga proses pembakaran. Bailey (2001) melaporkan bahwa HCB dapat terbentuk dari industry pestisida yang mengandung klorin, seperti atrazine, simazine, picloram, pentachloronitrobenzene (PCNB), chlorothalonil, dimethyl tetrachloroterephthalate (DCPA), pentachlorophenol, technical $\mathrm{HCH}$ and lindane. Selain itu HCB juga terdapat pada technical chlorothalonil dan pentachlorophenol (EPA, 1999). Chlorothalonil dipergunakan secara luas sebagai pestisida pada pertanian, lapangan golf, dan sebagai pengawet pada cat, resin, pengemulsi dan pelapis (coating). Sehingga tingginya konsentrasi HCB pada sampel water D kemungkinan berasal dari proses industry yang berada di sekitar lokasi pengambilan sampel. Hal ini diperkuat dengan hasil penelitian sebelumnya, dimana pada sampel tersebut juga ditemukan konsentrasi deca-CB (PCB IUPAC \#209) dan OCDF relative cukup tinggi. HCB, deca-CB (PCB IUPAC \#209) dan OCDF merupakan senyawa kimia yang berasal dari proses samping industry. Namun penelitian lebih lanjut sangat diperlukan untuk mengetahui sumber pencemar tersebut. Untuk pemantauan pestisida organoklorin pada air sungai, pemerintah telah menetapkan PP No. 82 Tahun 2001 tentang pengelolaan kualitas air dan pengendalian pencemaran air. Bila dibandingkan dengan kriteria mutu air berdasarkan PP No. 82 Tahun 2001, pada parameter pestisida organoklorin, kualitas air pada daerah studi masih jauh di bawah krtieria tersebut untuk air sungai kelas I, walaupun pada sampel water $\mathrm{D}$ terdeteksi HCB dengan konsentrasi tinggi. Namun selama tidak ada pengendalian terhadap sumber pencemarnya, maka pelepasan $\mathrm{HCB}$ ke lingkungan akan semakin meningkat di masa mendatang.

Bila dibandingkan dengan konsentrasi OCP pada penelitian sebelum pada ruas sungai Ciliwung (Iwata et al., 1991), maka konsentrasi OCPs pada penelitian ini lebih rendah. Sedangkan bila dibandingkan dengan negara lain, konsentrasi OCPs secara umum masih lebih rendah dibandingkan dengan air sungai di Cina dan 
Amerika Serikat, namun untuk HCB konsentrasinya lebih tinggi dari Peacock River, Cina (Tan et al.,
2009; Guan et al., 2009; Chen et al., 2010; Curren et al., 2011).

Table 4 : Konsentrasi OCPs di air (ng/L)

\begin{tabular}{lrrrrr}
\hline \multicolumn{1}{c}{ OCPs } & Water A & Water B & Water C & Water D & Water E \\
\hline \hline$\alpha-H C H$ & ND & 0.14 & 0.13 & 0.25 & 0.15 \\
$\beta-H C H$ & ND & ND & ND & ND & ND \\
Lindane $(\gamma-H C H)$ & 0.083 & 0.34 & 0.43 & 0.82 & 0.19 \\
$\delta$-HCH & ND & ND & ND & ND & ND \\
HCB & ND & ND & ND & 688.28 & 0.55 \\
Aldrin & ND & ND & ND & ND & ND \\
Dieldrin & ND & ND & ND & 0.29 & 0.18 \\
cis-heptachlor epoxide & ND & ND & ND & ND & ND \\
trans-heptachlor epoxide & ND & ND & ND & ND & ND \\
oxychlordane & ND & ND & ND & ND & ND \\
cis-chlordane & ND & ND & ND & 0.12 & 0.74 \\
trans-chlordane & ND & ND & ND & 0.14 & 0.89 \\
cis-nonachlor & ND & ND & ND & ND & 0.16 \\
trans-nonachlor & ND & ND & ND & ND & 0.48 \\
o,p'-DDE & ND & ND & ND & ND & ND \\
p,p'-DDE & ND & ND & ND & ND & 0.21 \\
o,p'-DDD & ND & ND & ND & ND & ND \\
p,p'-DDD & ND & ND & ND & ND & ND \\
o,p'-DDT & ND & ND & ND & ND & ND \\
p,p'-DDT & ND & ND & ND & ND & ND \\
Mirex & ND & ND & ND & ND & ND \\
\hline
\end{tabular}

Note:

Water A : Air tanah, Puncak Pass, Bogor

Water B : Air Sungai Ciliwung, Babakan, Gadog, Ciawi, Bogor

Water C : Air Sungai Ciliwung, Jl. Otista, Bogor

Water D : Air Sungai Ciliwung, Kapuk, Pluit, Jakarta

Water E : Air Sungai Kosambi, Tangerang, di dekat daerah tambak ikan bandeng

$\mathrm{ND}=$ not detected

Tabel 5 : Kriteria Mutu Air (KMA) berdasarkan PP No. 82 tahun 2001 tentang pengelolaan kualitas air dan pengendalian pencemaran

\begin{tabular}{|c|c|c|c|c|c|}
\hline \multirow{2}{*}{ Parameter } & \multirow{2}{*}{ Satuan } & \multicolumn{5}{|c|}{ Kelas } \\
\cline { 3 - 6 } & & $\mathrm{I}$ & $\mathrm{II}$ & $\mathrm{III}$ & $\mathrm{IV}$ \\
\hline Benzene hexachloride (BHC) & $\mu \mathrm{g} / \mathrm{L}$ & 210 & 210 & 210 & $(-)$ \\
\hline Aldrin dan Dieldrin & $\mu \mathrm{g} / \mathrm{L}$ & 17 & $(-)$ & $(-)$ & $(-)$ \\
\hline Klordan & $\mu \mathrm{g} / \mathrm{L}$ & 3 & $(-)$ & $(-)$ & $(-)$ \\
\hline DDT & $\mu \mathrm{g} / \mathrm{L}$ & 2 & 2 & 2 & 2 \\
\hline Heptaklor dan heptaklor epoksid & $\mu \mathrm{g} / \mathrm{L}$ & 18 & $(-)$ & $(-)$ & $(-)$ \\
\hline Lindan & $\mu \mathrm{g} / \mathrm{L}$ & 56 & $(-)$ & $(-)$ & $(-)$ \\
\hline Metoksiklor & $\mu \mathrm{g} / \mathrm{L}$ & 35 & $(-)$ & $(-)$ & $(-)$ \\
\hline Endrin & $\mu \mathrm{g} / \mathrm{L}$ & 1 & 4 & 4 & $(-)$ \\
\hline Toksaphen & $\mu \mathrm{g} / \mathrm{L}$ & 5 & $(-)$ & $(-)$ & $(-)$ \\
\hline
\end{tabular}

Ket (-) : tidak dipersyaratkan 


\section{KESIMPULAN}

Studi ini menampilkan informasi tentang kandungan OCPs dalam air pada area perkotaan di Jabodetabek. OCPs yang terdeteksi menunjukkan bahwa sumber pencemaran berasal dari penggunaan masa lalu bukan berasal penggunaan waktu sekarang. Hasil yang menarik adalah terdeteksinya HCB dalam konsentrasi yang cukup tinggi yang kemungkinan berasal dari pencemaran dari proses industry. Penelitian lebih lanjut dan penambahan titik sampel diperlukan untuk mengklarifikasi sumber pencemaran secara tepat, termasuk penggunaan lahan di sekitar titik sampel.

\section{DAFTAR PUSTAKA}

- Bailey, Robert E. 2001. Global hexachlorobenzene emission. Chemosphere 43: $167-182$.

- Chen, W., Jing, M., Bu, J., Burnet, J. E., Qi, S., Song, Q., et al. (2011). Organochlorine pesticides in the surface water and sediments from the Peacock River Drainage Basin in Xinjiang, China: a study of an arid zone in Central Asia. Environ. Monit. Assess., 177: 1-21.

- Curren Jane, Steven Bush, Simon Ha, Michael K. Stenstrom, Sim-Lin Lau, IH Mel Suffet. 2011. Identification of subwatershed sources for chlorinated pesticides and polychlorinated biphenyls in the Ballona Creek watershed. Sci. Total Environ. 409:2525-2533.

- Darko Godfred, Osei Akoto, Caleb Oppong. 2008. Persistent organochlorine pesticide residues in fish, sediments and water from Lake Bosomtwi, Ghana. Chemosphere 72: 21-24.

- Environmental Management Center (EMC). 2003. Monitoring of persistent organic pollutants (POPs) in the coastal hydrosphere of Indonesia. Country report UNU: Japan.

- Environmental Protection Agency (EPA). 1999. Reregistration Eligibility Decision (RED): Chlorothalonil. United States Environmental Protection Agency (US EPA) : Washington DC.

- Fair Patricia A., Jeff Adams, Gregory Mitchum, Thomas C. Hulsey, John S. Reif, Magali Houde, Derek Muir, Ed Wirth, Dana Wetzel, Eric Zolman, Wayne McFee, Gregory D. Bossart. 2010. Contaminant blubber burdens in Atlantic bottlenose dolphins (Tursiops truncatus) from two Southeastern US estuarine areas : Concentrations and pattern of PCBs, pesticides, PBDEs, PFCs, and PAHs. Sci. Total Environ. 408: 1577-1597.

- Guan Yu-Feng, Ji-Zhong Wang, Hong-Gang Ni, Eddy Y. Zeng. 2009. Organochlorine pesticides and polychlorinated biphenyls in riverine run off of the Pearl River Delta, China: Assessment of mass loading, input source and environmental fate. Environ. Pollution 157:618-624.

- Iwata Hisato, Shinsuke Tanabe, Norio Sakai, Atsushi Nishimura, dan Ryo Tatsukawa. 1994. Geographical distribution of persistent organochlorines in air, water, and sediments from Asia and Oceania, and their implications for global redistribution from lower latitudes. Environmental Pollution 85:15-33.

- Bloksom Karen A., David M. Walters, Terri M. Jicha, James M. Lazorchak, Theodore R. Angradi and David W. Bolgrien. 2010. Persistent organic pollutans in fish tissue in the mid-continental great rivers of the United States. Sci. Total Environ. 408: 1180-1189.

- Ratnaningsih, D., Helmy M., Bagus B.E., Nety W., Heni P. 2002. A survey on water pollution by endocrine disrupter compounds: Monitoring of organochlorine pesticides, phenols and phthalates in the coastal hydrosphere of Indonesia. Country report UNU: Japan.

- Shoiful, Ahmad, Hiroyuki Fujita, Isao Watanabe, Katsuhisa Honda. Concentrations of organochlorine pesticides (OCPs) residues in foodstuffs collected from traditional markets in Indonesia. Chemosphere 90 (2013) 1742-1750.

- Shoiful, Ahmad, Rudi Nugroho, Hiroyuki Fujita, Katsuhisa Honda. Konsentrasi polychlorinated biphenyls (PCBs) dan polychlorinated dibenzo-pdioxin/polychlorinated dibenzofurans (PCDD/PCDF) dalam air dari daerah perkotaan Jabodetabek. Jurnal Air Indonesia 7 (1) (2014) 1 10.

- Sudaryanto Agus, Tatsuya Kunisue, Natsuko Kajiwara, Hisato Iwata, Tussy A. Adibroto, Phillipus Hartono, Shinsuke Tanabe. 2006. Specific accumulation of organochlorines in human breast milk from Indonesia: Levels, distribution, accumulation kinetics and infant health risk. Environ. Pollut. 139: $107-117$.

- Tan, L., He, M.C., Men, B., Lin, C.Y., 2009. Distribution and sources of organochlorine pesticides in water and sediments from Daliao River estuary of Liaodong Bay, Bohai Sea (China). Estuarine, Coastal and Shelf Science 84, 119-127.

- Ueno D., T. Isobe, K. Ramu, S. Tanabe, M. Alaee, C. Marvin, K. Inoue, T. Someya, T. Miyajima, H. Kodama, H. Nakata. 2010. Spatial distribution of hexachlorocyclododecanes (HBCDs), polybrominated diphenyl ethers (PBDEs) and organochlorines in bivalves from Japanese coastal waters. Chemosphere 78 : 1213-1219.

- UNEP, 2001. Stockholm Convention on Persistent Organic Pollutants (POPs), Interim Secretariat for the Stockholm Convention, United Nations 
Environmental Programmer (UNEP) Chemicals: Geneva, Switzerland; <http://www.pops.int>.

- UNEP. 2002. Regionally Based assessment of Persistent toxic substances: South East Asia and South Pacific Regional Report. Global Environment Facility, Switzerland: Geneva.

- UNIDO. 1984. Indonesia: consultation on research and development for pesticide production in Indonesia, Technical report. United
Nations Industrial Development Organization: Vienna.

- Untung Kasumbogo. 1999. Management of Persistent Organic Pollutants in Indonesia. Proceedings of the Regional Workshop on the Management of Persistent Organic Pollutants (POPs). UNEP. Hanoi, Vietnam, 16-19 March 1999. 